\title{
Digital Mind-Mapping to Improve Learners' Grammar Competence
}

\author{
Afi Normawati \\ Universitas Nasional Karangturi \\ Semarang, Indonesia \\ afi.norma@gmail.com
}

\begin{abstract}
Grammar has always been an important element of linguistic competence to be mastered in EFL contexts. The ways to teach and to make learners use grammar correctly have been the goals in grammar classes. This paper reports a study aimed at finding out if a grammar learning strategy called Digital Mind-Mapping (DMM) can improve learners' grammar competence. The study was conducted in Universitas Nasional Karangturi Semarang involving first-semester students taking Words and Phrase Grammar (WPG) class. In the study, the researcher tried to discover the feasibility of DMM to be applied in grammar teaching and learning process since it involves the use of different platforms such as Instragram and WhatsApp in the learning processes. The study used a quantitative approach. The data were in the forms of students' scores. They were collected by doing pretest and post-test. Data analysis was carried out by using t-test. The findings show that DMM seems to have great potential to be used in grammar classes since it helps improve the students' grammar competence.
\end{abstract}

Keywords: grammar, grammar competence, Mind-Map, Digital Mind-Mapping 


\section{Introduction}

Grammar is an essential component in language. However, language learners have difficulty in learning a language that is not their mother tongue. This is a challenge for grammar teachers to find a strategy that can help learners learn grammar more effectively. Effective learning occurs when students are actively involved in understanding learning material, and this can be facilitated by mindmapping. To increase motivation in learning, the use of digital media that is of interest to the learners needs to be considered. Therefore, Digital Mind-Mapping (DMM) can be used in grammar learning. Based on the background, this research was conducted to find out whether DMM is effective to improve learners' grammar.

\section{Literature Review}

Grammar is important and must be mastered in language learning. It is a set of rules that describe how words, phrases, clauses and sentences produce meaning (Swan, 2005). All languages have grammar; therefore, the use of proper grammar is very important to make communication meaningful. People who speak the same language, who know the grammar, can communicate because they can create and exchange meaning. Communication that is easy to understand is not possible without proper use of grammar. The better the grammar, the clearer the message, so the greater the possibility of the recipient to understand the meaning of the message (Bradshaw, 2013). For this reason, grammar must be 
learned first in language learning. Given the importance of grammar, effective activities must be set to help learners learn grammar. The objectives of the activities are for the learners to understand grammar concepts and be able to use them appropriately. Understanding a concept requires a structured way of thinking, and this can be achieved by using mind-map, a very powerful tool for brainstorming, creative thinking, problem solving, organising ideas and taking notes (Buzan, 2005). Using mind-map allows human brain to process various thoughts and information (Davies, 2011).

Mind-map shows the relationship between ideas visually. The main information is located in the middle of the map and the sub-information is radiated from the main information and located around the main information (Murley, 2007). Mind-map can be drawn by using paper and pen or with computer application or digital tool. To create a mind-map, the first step is to set the main purpose or the main idea of the mind-map. Put the subject matter of the map in the centre, and map out the subtopics or information related to the main idea. After that, add keywords that give information about the subtopics. To outline more detailed information, have other branches that spread out of the subtopics. Continue to draw the chart containing more details that are relevant to the concept. The last step is to add colours, symbols and images to the map. Colours can be applied on the branch lines, the texts or background of the texts.

A mind-map design that radiates makes the main topic or idea in the centre and the subtopics stay near the main topic. This keeps the big picture in 
focus and the connections between ideas are easy to see. Mind-map can improve students' creativity and memory because instead of writing in the form of descriptions, using a mind-map is flexible, and it can display all relevant information on the same map. Mind-map also gives learners a more interesting and pleasing format to see, then allows it to be processed by the learners' brains. This makes learners remember information more easily as emphasis and relationships are indicated by images, symbols and colours (Budd, 2004).

In addition to the use of mind-map to support the learning process, effective tools also need to be chosen carefully. One of the tools that can be used to facilitate learning is social media. Social media is an effective tool to use because it is authentic (Handayani \& Solok, 2016). Social media platforms that are familiar for learners nowadays are Instagram and Whatsapp. These tools allow learners to share knowledge and information, such as mind-maps that the learners have made. These tools are chosen for their popularity and convenience as they are easy to use (user-friendly).

The researcher named the learning strategy that uses mind-map and social media as Digital Mind-Mapping (DMM). The term digital is used because digital means related to computers, especially the internet (Cambridge Dictionary, n.d.). Digital Mind-Mapping refers to activity to create mind-map by using digital tools, and use and share it through internet connection by using social media platforms. 


\section{Method}

The research used one-group pre-test-post-test design. The design of the research compares the scores in a pre-test to the scores of a post-test after a treatment. The model of one-group pre-test-post-test design is represented as follows:

\begin{tabular}{|c|c|c|}
\hline Pre-test & Treatment & Post-test \\
\hline O1 & $\mathrm{X}$ & $\mathrm{O} 2$ \\
\hline
\end{tabular}

Table 1. One-group pre-test-post-test (Sugiyono, 2001)

The study was conducted in Universitas Nasional Karangturi Semarang involving first-semester students taking Words and Phrase Grammar (WPG) class. At the first meeting, the students were given a pre-test to determine their knowledge on the parts of speech. In the test, there were some sentences with one underlined word in each sentence.

The students were asked to decide whether each underlined word is a noun, pronoun, adjective, verb, adverb, conjunction, preposition, or interjection. After submitting the answers, the students were given an explanation on what they would do during the next meetings. The lecturer told the students that they would have Digital Mind-Mapping (DMM) and explained how to make a mind-map. In the next eight meetings, the lecturer gave explanation about parts of speech and involved the students to have discussion. The lecturer discussed one part of speech 
for each meeting. After the discussion of each part of speech, the students were given assignment to make a mind-map about the part of speech that had been discussed in the meeting, then posted it on their Instagram so that their friends could see the mind-map. The objective was to encourage the students to make a mind-map that had comprehensive outline about the part of speech discussed. After that, the students were asked to send the mind-map they had posted on WhatsApp group so that their friends could comment and ask questions related to the mind-map. In the next meeting, before the class started by asking some students to show their mind-map and explained it to their friends. After eight meetings, the students were given a post-test to see the result of the treatment. The instruction and items on the post-test were the same as those on the pre-test.

\section{Results and Discussions}

The researcher verified the normality and homogeneity of the data by using Liliefors testing before analysing the results of the pre-test and post-test.

The formula used to find out the normality of the data is:

$$
z_{i}=\frac{X-\bar{X}}{s}
$$

where

$$
s=\sqrt{\frac{(X-\bar{X})^{2}}{n-1}} \text { or } \sqrt{\frac{\sum X^{2}-\frac{\left(\sum X\right)^{2}}{n}}{n-1}} \text { or } \sqrt{\frac{\sum x^{2}}{n-1}}
$$


The data is in normal distribution if $\mathrm{L}$ obtained $\left(\mathrm{L}_{\mathrm{o}}\right)$ is lower than $\mathrm{L}$ table $\left(L_{t}\right)$ at the significant degree $\alpha=0.05$.

The result of the normality test is shown in the table below:

\begin{tabular}{|l|l|l|l|l|}
\hline & $\mathrm{L}_{\mathrm{o}}$ & & $\mathrm{L}_{\mathrm{t}}$ & \\
\hline Pre-test & 0.111 & $\leq$ & 0.285 & 0.05 \\
\hline Post-test & 0.264 & $\leq$ & 0.285 & 5 \\
\hline
\end{tabular}

Table 2. The result of the normality test

The table shows that $\mathrm{L}_{0}$ of the pre-test is $0.111, \mathrm{~L}_{0}$ of the post-test is 0.264 and $\mathrm{L}_{\mathrm{t}}$ is 0.285 . Therefore, it can be concluded that the data are in normal distribution.

After obtaining the result of the normality test, the researcher then determined whether the data are homogeneous or not. The formula used to test the homogeneity of the data is:

$$
\text { Ftest }=\frac{\text { varian terbesar }}{\text { varian terkercil }}
$$

The result of the homogeneity test is shown in the table below:

\begin{tabular}{|l|l|l|l|}
\hline $\mathrm{X}_{\mathrm{o}}{ }^{2}$ & & $\mathrm{X}_{\mathrm{t}}^{2}$ & \\
\hline 3.22 & $\leq$ & 5.59 & 0.05 \\
\hline
\end{tabular}

Table 4. Result of the F-test

After verifying the normality and homogeneity of the data, the researcher identified the level of mean difference by using t-test. 
The result of the t-test is shown in the table below:

\begin{tabular}{|l|l|l|l|}
\hline & Mean & \multicolumn{1}{|c|}{$\mathrm{t}_{\mathrm{o}}$} & $\mathrm{t}_{\mathrm{t}}$ \\
\hline Pre-test & 7.625 & & \\
\hline & & 4.25 & 1.94 \\
\hline Post-test & 11.375 & & \\
\hline
\end{tabular}

Table 4. Result of the t-test

The table shows that the mean score of the pre-test is 7.625 , the mean score of the post-test is $11.375, \mathrm{t}_{\mathrm{o}}$ is 4.25 and $\mathrm{t}_{\mathrm{t}}$ is 1.94 . $\mathrm{L}_{\mathrm{o}}$ is higher than $\mathrm{L}_{\mathrm{t}}$. Therefore, it can be concluded that there is significant improvement on the students' grammar after they learned grammar by using DMM.

Based on the pre-test and post-test result analysis, the researcher found that the students have made progress on their understanding of parts of speech. This can be seen in the result of the pre-test and post-test and the analysis of the results. At the first meeting, when the researcher asked whether or not the students could differentiate each part of speech, most of the students answered that it was difficult for them to do it. They did not know the concept of parts of speech. After the researcher explained that they would learn about parts of speech by using DMM, the students admitted that DMM was new for them since they had not used that strategy before. The students had not been exposed to the use of mind-map in their learning. Furthermore, they never made mind-map before. This became a challenge as well as an opportunity for the researcher to see if the strategy would 
be successful in the students' learning. The researcher then explained that in the next meeting, she would deliver the material by giving linear explanation to the students. The explanation would be about parts of speech. She would explain one part of speech for each meeting. After that, the students were asked to make a mind-map based on the explanation and discussion in each meeting.

This strategy allowed the students to analyse the ideas and information in the discussion. When they were asked to create a mind-map, they were forced to focus on the explanation and discussion. In addition, the students needed to write down the information of the lecture and interpret the information. Thereafter, in creating a mind-map, they organised the information in a way that made it easy for them to understand. The activities needed strong analysis by the students since they had to prioritise and chategorise information. This also needed them to think systematically because they had to structure the information to make a comprehensive and understandable mind-map, and the mind-map they made would be comprehensible when it showed logical relationship between ideas and information. In addition, to make it more interesting and easier to memorise information in the mind-map, the students added colour. The students were encouraged to make their mind-maps interesting because they were asked to posted the mind-maps on their social media.

The strategy was effective in the students' grammar learning. This was proven by the significant increase in their test result. Besides, the students claimed 
that this strategy made them focus on the lectures and recall the materials taught in each lecture.

\title{
Conclusion
}

DMM is a learning strategy which allows learners to create mind-map by using digital tools, and use and share it through internet connection by using social media platforms. By creating a mind-map, learners can categorise information and ideas and recognise the connection between ideas. This strategy encourages learners to focus on lectures and discussions about materials in Grammar class and to think systematically as well. Therefore, it can be concluded that DMM is effective in grammar learning.

\begin{abstract}
About the Writer
Afi Normawati is and English Lecturer who is currently teaching at Universitas Nasional Karangturi, Semarang, Central Java, Indonesia. Her research interest is in language skills and components and in methods in language teaching. She can be reached at afi.norma@gmail.com
\end{abstract}

\section{References}

Bradshaw, W. W. (2013). Why Grammar Is Important. https://www.huffpost.com/entry/why-grammar-is-important_b_4128521

Budd, J. W. (2004). Mind maps as classroom exercises. Journal of Economic 
Education, 35(1), 35-46. https://doi.org/10.3200/JECE.35.1.35-46

Buzan, T. (2005). The Mind Map Handbook. Thorsons.

Cambridge

Dictionary.

(n.d.).

https://dictionary.cambridge.org/dictionary/english/digital

Davies, M. (2011). Concept Mapping, Mind Mapping and Argument Mapping: What Are the Differences and Do They Matter? Higher Education, 62, 279301. https://doi.org/https://doi.org/10.1007/s10734-010-9387-6

Handayani, F., \& Universitas Mahaputra Muhammad Yamin Solok, Mp. (2016). Igniting a Brighter Future of EFL Teaching and Learning in Multilingual Societies INSTAGRAM AS A TEACHING TOOL? REALLY? Proceedings of the Fourth International Seminar OnEnglish Language and Teaching (ISELT-4), 320-327.

Murley, D. (2007). Mind Mapping Complex Information. Law Library Journal, $175-183$.

Sugiyono. (2001). Metode Penelitian Kuantitatif dan R\&D. Alfabeta.

Swan, M. (2005). Practical English Usage. Cornelsen \& Oxford University Press. 